\title{
Role of Halides on the Passivation of Iron in Alkaline Buffer Solutions
}

\author{
S. Nathira Begum, C. Ahmed Basha, ${ }^{*}$ V.S. Muralidharan \\ Central Electrochemical Research Institute, Karaikudi-630 006, India
}

Received 14 November 2009; accepted 08 April 2010

\begin{abstract}
Cyclic voltammetric studies were carried out on pure iron in alkaline borate and phosphate buffer solutions at $\mathrm{pH}$ 10.8. At higher potentials, on anodic polarization, iron forms $\mathrm{FeB}_{4} \mathrm{O}_{7}$ and $\mathrm{FeOOH}$ in borate buffer, and $\mathrm{FeHPO}_{4}$ in phosphate buffer which got converted to higher valency phosphates.

In phosphate solutions, in presence of halides, the interfacial diffusion layer turned to be cation selective outer sublayer and an anion selective inner sublayer, and in borate solutions a precipitate layer of metal oxyhydroxide was formed, which was anion selective, and anions adsorb on this.
\end{abstract}

Keywords: iron, cyclic voltammetry, passivity, alkaline corrosion, interfaces, anodic films.

\section{Introduction}

Over a long period it was supposed that the electrons are the only particles taking part in metal dissolution [1]. When metal dissolves anions and solvent molecules participate in complex formation, the adsorbed water forms surface charge transfer complexes (SCTC) with surface atoms of the transition metals. Studies on iron dissolution in acetonitrile solutions with small amounts of water confirmed this [2]. The formation of adsorbed complexes $\left[\mathrm{M}-\mathrm{H}_{2} \mathrm{O}\right]_{\text {ads }}$ is accompanied by a partial charge transfer from the water molecules to the metal. In presence of various anions, iron dissolution was explained invoking the participation of SCTC and mechanistic schemes.

Many studies about active dissolution and passivation were carried in alkaline solution [3-12] and many electrochemical studies have been investigating the behaviour of iron in aqueous solution. Several mechanisms have been suggested

\footnotetext{
*Corresponding author. E-mail address: basha@cecri.res.in,cab_50@rediffmail.com
} 
[3-9] but no consensus has yet been found by different authors. However, the majority of authors propose the existence of an intermediate transient species, $\mathrm{Fe}(\mathrm{I})$, generally designated as $\mathrm{FeOH}_{\mathrm{ads}}$, although there is little, if any, direct evidence for its existence [4,13-14]. In the presence of a sufficient quantity of $\mathrm{OH}^{-}$and / or an aggressive anion, $\mathrm{A}^{-}$, competitive adsorption between water molecules and anions may occur, which means that surface attack occurs by forming $\mathrm{Fe}\left[\mathrm{H}_{2} \mathrm{O}\right]$ or $\mathrm{Fe}\left(\mathrm{A}^{-}\right)$groups [4]. If $\mathrm{A}^{-}$forms an iron soluble salt, the corrosion is not uniform. If the salt is insoluble, $\mathrm{A}^{-}$may assist passivation depending on its capacity for homogeneously covering the metallic surface increasing the ionic charge transfer resistance [4]. The species $\mathrm{Fe}\left[\mathrm{H}_{2} \mathrm{O}\right]$ or $\mathrm{Fe}\left(\mathrm{OH}^{-}\right)$initiate the oxidation process by electrochemical deprotonation reactions $[4,5,14]$. Under potentiodynamic conditions, the first anodic peak is specifically related to $\mathrm{Fe}(\mathrm{OH})_{2}$ formation and the second peak to $\mathrm{Fe}(\mathrm{OH})_{2}$ with three dimensional oxide film, and the third peak to FeOOH formation [15-18]. From the variation of the peak height as a function of sweep rate and hydroxide concentration [19], the film growth on the surface was assigned to low field migration of ions through an oxide/hydroxide lattice. Again, the three anodic peaks observed $[20,21]$ had been assigned to the ionization of adsorbed hydrogen, $\mathrm{Fe}(\mathrm{OH})_{2}$ and $\mathrm{Fe}_{3} \mathrm{O}_{4}$ formation.

The present investigation deals with the participation of halide ions in the passivation of iron in alkaline borate and phosphate buffer solutions. Cyclic voltammetric studies were carried out to understand the influence of halides on the iron dissolution and passivation.

\section{Materials and methods}

The working electrode was made of pure iron rod $(99.9999 \%$ purity, Johnson Matthey Chemicals Ltd., U.K) with a circular area of $0.2 \mathrm{~cm}^{2}$. The rod was embedded in Teflon gaskets and electrical connections were provided by screw and thread arrangement. The surface of the electrode was polished successively with finest grade emery papers and with $0.05 \mu \mathrm{m}$ alumina, degreased with trichloroethylene and washed with running double distilled water. The counter electrode was a platinum sheet of $4 \mathrm{~cm}^{2}$ area and a $\mathrm{Hg} / \mathrm{HgO} / \mathrm{OH}^{-}$ion electrode was used as reference. A potentiostat /galvanostat Model IM6 was used for obtaining cyclic voltammograms (CVs). The experiments were carried out in borate and phosphate buffer solutions kept at $\mathrm{pH} 10.8$ in presence and absence of different concentrations of halide ions $\left(\mathrm{Cl}^{-}, \mathrm{Br}^{-}\right.$and $\left.\mathrm{I}^{-}\right)$. All solutions were deoxygenated with purified $\mathrm{N}_{2}$. Each experiment was performed with freshly prepared solutions and on freshly prepared surface. All measurements were performed at $30 \pm 1{ }^{\circ} \mathrm{C}$. The potentiodynamic polarization curves were recorded by changing the potential automatically at the desired sweep rate.

In order to start with a clean surface, the electrode was kept at $-1.5 \mathrm{~V}$ or $-1.2 \mathrm{~V}$, depending on the buffer solution, for half an hour, disconnected shaken free of adsorbed hydrogen and then subjected to triangular potential scan at various sweep rates. The potential range $-1.3 \mathrm{~V}\left(\mathrm{E}_{\lambda \mathrm{c}}\right)$ to $+1.2 \mathrm{~V}\left(\mathrm{E}_{\lambda_{\mathrm{a}}}\right)$ was fixed at a sweep 
rate of $100 \mathrm{mVs}^{-1}$ after several experiments to get reproducible potential versus current.

\section{Results and discussion}

The results of the experiments carried out are presented in Figs. 1 to 5 and Table 1. Oxidation and reduction processes occurring on an iron electrode in alkali solutions were reviewed and reported $[16,17]$. The first anodic peak in cyclic voltammograms is specially due to $\mathrm{Fe}(\mathrm{OH})_{2}$ formation, the second anodic peak to $\mathrm{Fe}(\mathrm{OH})_{2}$ with three dimensional oxide films, and the third peak to $\mathrm{FeOOH}$ formation $[17,18]$. Oxidation of iron occurs as

$$
\begin{gathered}
\mathrm{Fe}+\mathrm{OH}^{-} \leftrightarrows \mathrm{FeOH}_{\mathrm{ads}}+\mathrm{e}^{-} \\
\mathrm{FeOH}_{\mathrm{ads}} \leftrightarrows \mathrm{FeOH}_{\mathrm{ads}}^{+}+\mathrm{e}^{-} \\
\mathrm{FeOH}_{\mathrm{ads}}^{+}+\mathrm{OH}^{-} \leftrightarrows \mathrm{Fe}(\mathrm{OH})_{2} \\
\mathrm{Fe}(\mathrm{OH})_{2}+\mathrm{OH}^{-} \rightarrow \mathrm{FeOOH}+\mathrm{H}_{2} \mathrm{O}+\mathrm{e}^{-} \\
2 \mathrm{FeOOH} \leftrightarrows \mathrm{Fe}_{2} \mathrm{O}_{3} \cdot \mathrm{H}_{2} \mathrm{O}
\end{gathered}
$$

X-ray diffraction studies on oxide of iron [22] revealed that $\mathrm{Fe}_{2} \mathrm{O}_{3}$ to be present in all passive films independent of $\mathrm{pH}$. Ellipsometric responses of iron electrode in alkali showed [23] a composite structure of the passivating layer involving an inner layer, which is difficult to electro-reduce probably related to $\mathrm{Fe}_{3} \mathrm{O}_{4}$, and an outer gelatinous iron hydroxide layer which is reducible. One is a compact barrier film adjacent to the metal, and another is an outer strongly hydrated film [24].

\section{Electrochemical behaviour in phosphate buffer solutions}

When polarized from $-1200 \mathrm{mV}$ to $+100 \mathrm{mV}$, the forward scan exhibited a peak at $-395 \mathrm{mV}$. On reversing the scan, zero current crossing potential (ZCCP) appeared at $-404 \mathrm{mV}$. A cathodic peak appeared at $-590 \mathrm{mV}$ (Fig. 1). Appearance of an anodic peak at $-395 \mathrm{mV}$ suggests that iron was oxidized to divalent state and the oxidation proceeds in $\mathrm{pH} 10.8$ as

$$
\begin{gathered}
\mathrm{Fe}+\mathrm{OH}^{-} \leftrightarrows \mathrm{FeOH}_{\mathrm{ads}}+\mathrm{e}^{-} \\
\mathrm{FeOH}_{\mathrm{ads}} \leftrightarrows \mathrm{FeOH}_{\mathrm{ads}}^{+}+\mathrm{e}^{-} \\
\mathrm{FeOH}_{\mathrm{ads}}^{+}+\mathrm{HPO}_{4}^{-2} \rightarrow \mathrm{FeHPO}_{4}+\mathrm{OH}^{-}
\end{gathered}
$$

The phosphate layer thickened with increase in anodic potentials. While reversing the scan the appearance of a cathodic peak was due to 


$$
\mathrm{FeHPO}_{4}+\mathrm{e}^{-}+\mathrm{H}_{2} \mathrm{O} \longrightarrow \mathrm{FeOH}_{\mathrm{ads}}+\mathrm{H}^{+}+\mathrm{HPO}_{4}^{-2}
$$

which underwent reduction to iron at extreme cathodic potentials along with $\mathrm{H}_{2}$.

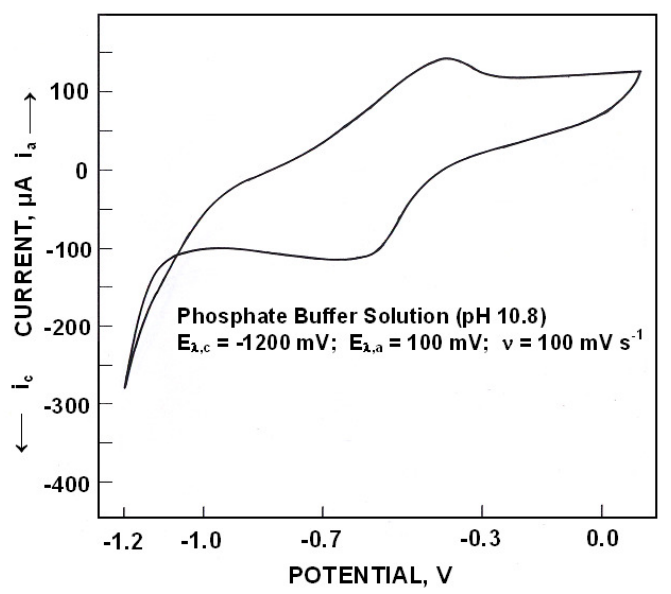

Figure 1. Cyclic voltammograms for iron in phosphate buffer solution of $\mathrm{pH} 10.8$.

Fig. 2a presents the electrochemical spectrum obtained in presence of various concentrations of chloride ions. An anodic peak appeared at $-410 \mathrm{mV}$ whose peak potentials and peak currents did not vary with chloride concentration. On reversing the scan, a cathodic peak appeared at $-450 \mathrm{mV}$. Cathodic peak potentials became noble while peak currents decreased with chloride concentration.

When polarized from $-1200 \mathrm{mV}$ to $+100 \mathrm{mV}$, the forward scan in different concentrations of bromide ions (Fig. 2b) exhibited an anodic peak at $-400 \mathrm{mV}$ whose peak potentials and peak currents did not vary with concentration. Cathodic peak appeared in the reverse scan at $-625 \mathrm{mV}$. Cathodic peak potentials became active while the peak currents were invariant.

Fig. 2c presents the electrochemical behaviour in different concentrations of iodide ions. An anodic peak appeared at $-400 \mathrm{mV}$. Anodic peak currents and potentials were invariant with iodide concentration. On reversing the scan a cathodic peak appeared at $-600 \mathrm{mV}$. Cathodic peak potentials did not vary with iodide ion concentrations while the peak currents decreased.

Role of anions on the dissolution, passivation and pitting was reviewed recently [25]. In phosphate solutions, iron phosphate along with iron hydroxyl polymers may be formed in the interfacial diffusion layer. These metal complexes are immobile and may provide a positively charged layer similar to ion selective membranes. In presence of halides, the interfacial layer gets modified. On anodic polarization, adsorption of phosphate ions on the surface takes place with oxygen atoms of the phosphate group pointing towards the metal. The outer layer surface being positively charged facilitates the adsorption of halides, consequently the interfacial diffusion layer turns to be cation selective outer sub layer originally present and an anion selective inner sublayer. Such a bipolar layer is resistive to ferrous ion transport, the reverse bipolarity to anodic current. 
The observed invariance of anodic and cathodic peak currents in presence of halide ion concentration confirms this.

a)

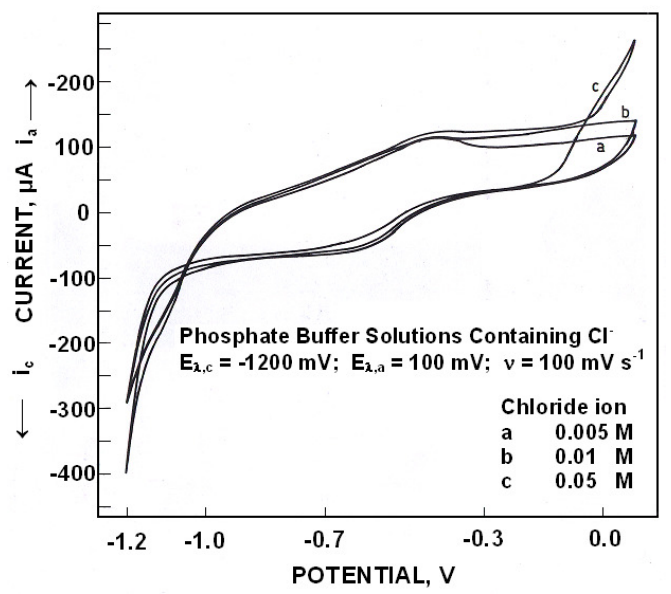

b)

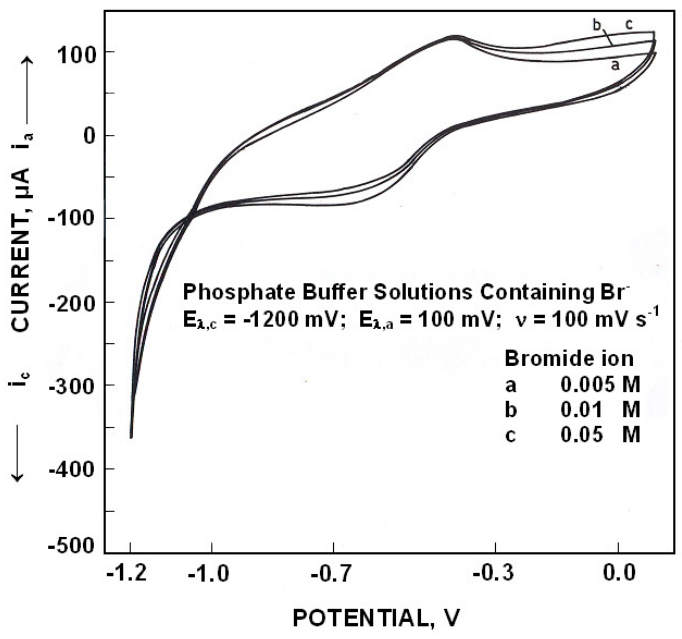

c)

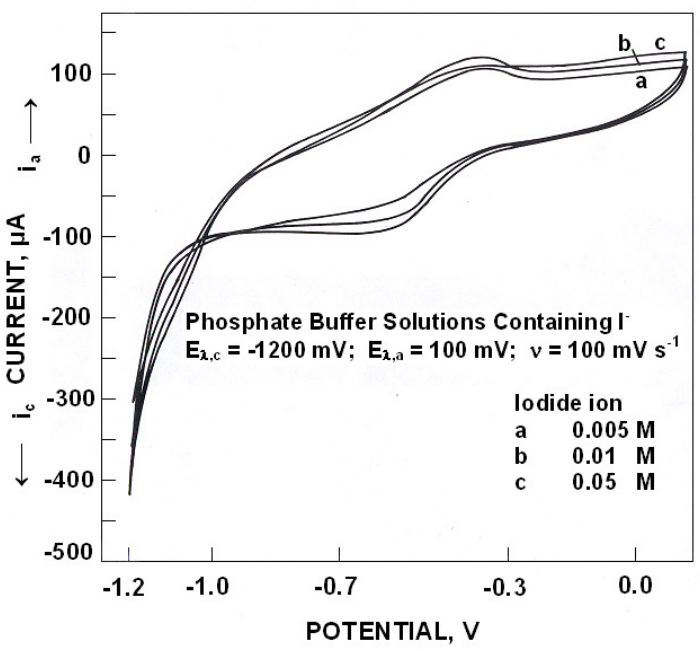

Figure 2. Cyclic voltammograms for iron in phosphate buffer solutions of $\mathrm{pH} 10.8$ containing different concentrations of a) $\mathrm{Cl}^{-}$ions, b) $\mathrm{Br}^{-}$ions and c) $\mathrm{I}^{-}$ions. 


\section{Electrochemical behaviour in borate buffer solutions}

Fig.3 presents the electrochemical spectrum obtained in borate buffer solutions, when polarized from $-1500 \mathrm{mV}$ to $+500 \mathrm{mV}$ the forward scan exhibited an anodic peak at $-883 \mathrm{mV}$ (I) followed by a broad peak in the range of $-300 \mathrm{mV}$ (II). On reversing the scan a cathodic peak appeared at $-592 \mathrm{mV}$ (III) followed by a peak (IV) at $-1330 \mathrm{mV}$.

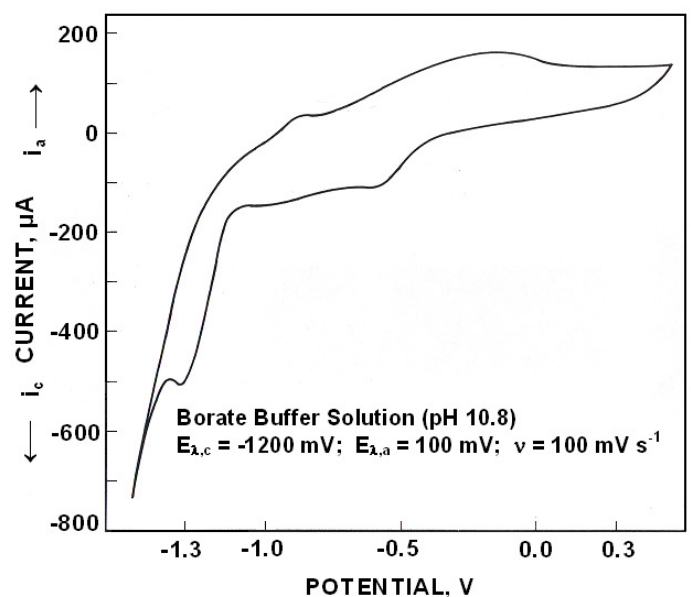

Figure 3. Cyclic voltammograms for iron in borate buffer solutions of $\mathrm{pH} 10.8$.

In the presence of chloride ions the electrochemical spectrum was modified (Fig. 4a). During the forward scan in $0.005 \mathrm{M} \mathrm{Cl}^{-}$solutions, an anodic peak (I) appeared at $-140 \mathrm{mV}$, whose peak potentials became active with increase in $\mathrm{Cl}^{-}$ ion concentration; current crossing appeared at $+150 \mathrm{mV}$. While reversing the scan, two cathodic peaks appeared at $-700 \mathrm{mV}$ (II) and at $-1200 \mathrm{mV}$ (III). Cathodic peak potentials became nobler with chloride ion concentration.

Fig. $4 \mathrm{~b}$ presents the cyclic voltammograms obtained in various concentrations of bromide ions. Broad anodic peak (I) appeared at $-310 \mathrm{mV}$ in $0.005 \mathrm{M}$ solutions which became active with increase in concentration. While reversing the scan around $+150 \mathrm{mV}$, current crossing appeared. Cathodic peaks appeared at -670 $\mathrm{mV}$ (II) and at $-1100 \mathrm{mV}$ (III). Cathodic peak potentials became nobler with bromide ion concentration.

When polarized from $-1500 \mathrm{mV}$ to $+500 \mathrm{mV}$, the forward scan exhibited a shoulder (I) at $-850 \mathrm{mV}$ followed by a peak at $-350 \mathrm{mV}$ (II) (Fig. 4c). Anodic peak potentials (II) became active with increase in iodide ion concentrations. While reversing the scan, a cathodic peak appeared at $-650 \mathrm{mV}$ (III) followed by a peak at $-1350 \mathrm{mV}$ (IV). Cathodic peak potentials became nobler with iodide ion concentration.

In borate buffer solutions, the interfacial layer consists of ferrous hydroxo complexes and their polymers. These metal complex ions and polymer ions are less mobile than simply hydrated ions. With progress in polymerization of metal hydroxo complexes, a precipitate layer of metal oxyhydroxide may be formed which is anion selective. Anions get adsorbed on the surface. 
a)

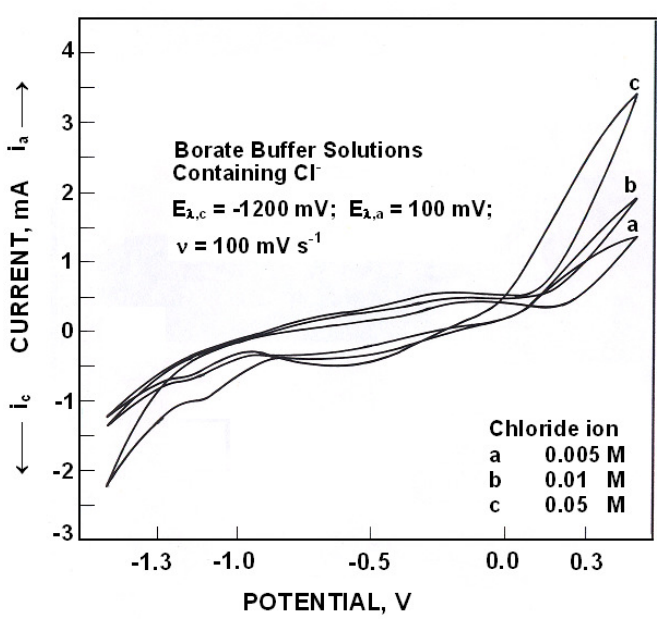

b)

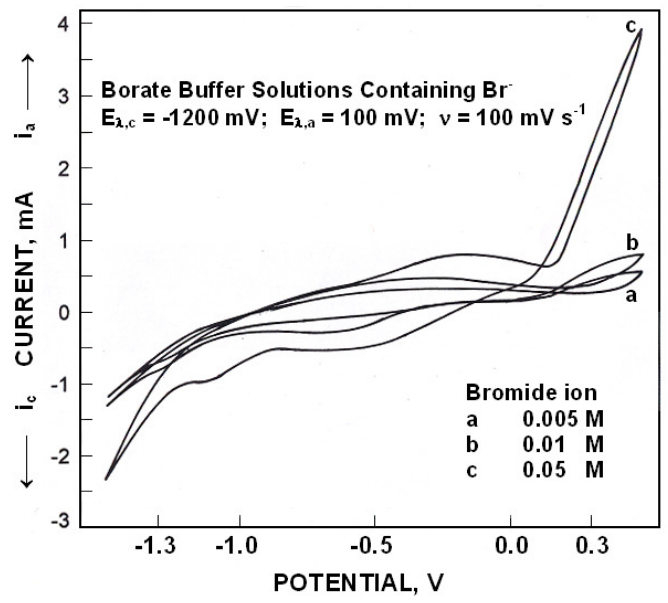

c)

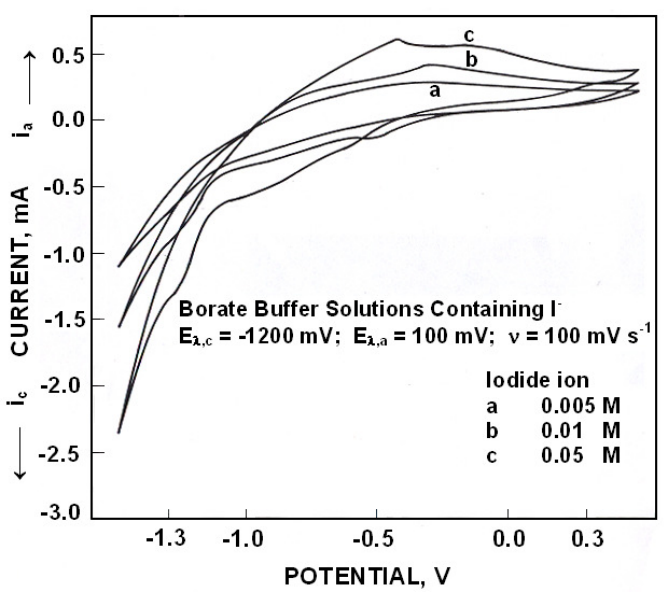

Figure 4. Cyclic voltammograms for iron in borate buffer solutions of $\mathrm{pH} 10.8$ containing different concentrations of a) $\mathrm{Cl}^{-}$ions, b) $\mathrm{Br}^{-}$ions and $\left.\mathbf{c}\right) \mathrm{I}^{-}$ions. 


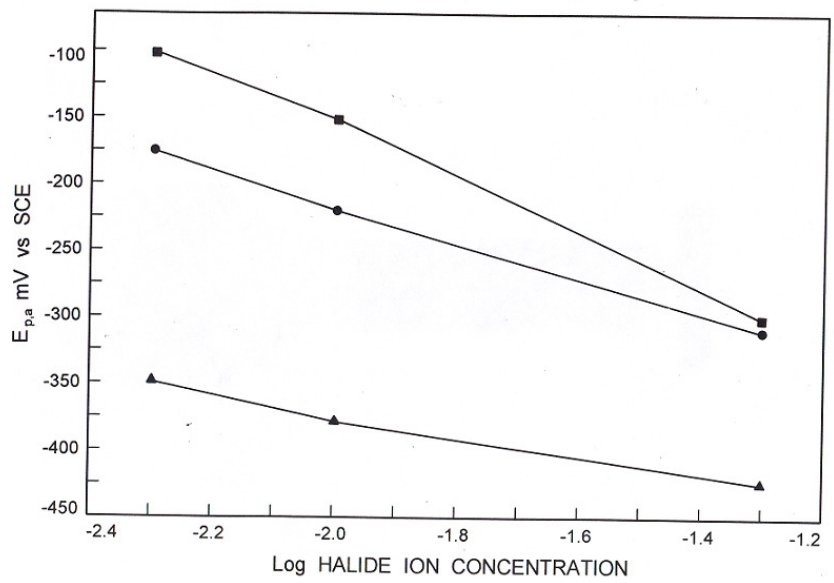

Figure 5. Variation of $\mathrm{E}_{\mathrm{p}, \mathrm{a}}$ with $\log$ [halide ion concentration].

Fig.5 presents the variation of anodic peak potential with log (halide ion concentration) in borate buffer solutions. The variation of $\mathrm{E}_{\mathrm{pa}}$ with $\log \left[\mathrm{X}^{-}\right]$ suggests the participation of halide ions

$$
\begin{gathered}
\mathrm{Fe}+\mathrm{OH}^{-} \leftrightarrows \mathrm{FeOH}_{\mathrm{ads}}+\mathrm{e}^{-} \\
\mathrm{FeOH}_{\mathrm{ads}} \leftrightarrows \mathrm{FeOH}_{\mathrm{ads}}^{+}+\mathrm{e}^{-} \\
\mathrm{FeOH}_{\mathrm{ads}}^{+}+\mathrm{B}_{4} \mathrm{O}_{7}^{2-} \rightarrow \mathrm{FeB}_{4} \mathrm{O}_{7}+\mathrm{OH}^{-} \\
\mathrm{FeX}_{2}+2 \mathrm{H}_{2} \mathrm{O} \rightarrow \mathrm{FeOOH}+2 \mathrm{X}^{-}+3 \mathrm{H}^{+}+\mathrm{e}^{-}
\end{gathered}
$$

where $\mathrm{X}^{-}$is a halide ion. Increase of halide ion concentration enhanced the anodic peak currents confirming the participation of halide ions (Table 1).

Table 1. Variation of anodic peak currents with halide concentration.

\begin{tabular}{cccc}
\hline $\begin{array}{c}\text { Concentration } \\
\mathbf{M}\end{array}$ & \multicolumn{3}{c}{$\mathbf{I}_{\mathbf{p}, \mathbf{a}}(\boldsymbol{\mu A})$} \\
\cline { 2 - 4 } $\mathbf{C l}^{-}$ & $\mathbf{B r}^{-}$ & $\mathbf{I}^{-}$ \\
\hline 0.005 & 471 & 290 & 257 \\
0.01 & 499 & 364 & 277 \\
0.05 & 800 & 730 & 666 \\
\hline
\end{tabular}

\section{Conclusions}

Iron underwent passivation in alkaline buffered phosphate and borate solutions. On anodic polarization iron formed $\mathrm{FeHPO}_{4}$ which got converted to higher valent phosphates at higher potentials in phosphate solutions. In borate buffer solutions, iron forms $\mathrm{FeB}_{4} \mathrm{O}_{7}$ and $\mathrm{FeOOH}$ on higher potentials.

In phosphate solutions in presence of halides, the interfacial layer got modified. The interfacial diffusion layer turned to be cation selective outer sublayer originally present and an anion selective inner sublayer. In borate solutions a precipitate layer of metal oxyhydroxide was formed, which was anion selective and anions adsorb on this. 


\section{Acknowledgement}

Our sincere thanks are due to the Director, Central Electrochemical Research Institute for all his encouragements.

\section{References}

1. B. Kabanov, R. Burstein, A. Frumkin, Disc. Faraday Soc. 259 (1974) 1.

2. Ya. Kolotrykin, M. Lazorenko, R.M. Manevich, L.A. Sokolova, Electrokhimiya 30 (1994) 537.

3. S.T. Amaral, I.L. Muller, Corros. Sci. 41 (1999) 759. [10.1016/S0010938X(98)00149-8]

4. J.R. Vilche, A.J. Arvia, Anal. Acad. Nac. Cs. Ex. Fis. Nat. 33 (1981) 100.

5. D.M. Drazic, C.S. Chao, Electrochim. Acta 27 (1982) 1409. [10.1016/00134686(82)80031-5]

6. J. Zou, D. Chin, Electrochim. Acta 33 (1988) 477. [10.1016/0013-4686(88)80164-6]

7. J. Zou, D. Chin, Electrochim. Acta 32 (1987) 1751. [10.1016/00134686(87)80010-5]

8. J. Flis, H. Oranowska, Z. Szklarska-Smialowska, Corros. Sci. 30 (1990) 1085. [10.1016/0010-938X(90)90058-D]

9. R.D. Armstrong, I. Baurhoo, J. Electroanal. Chem. 34 (1972) 41. [10.1016/S0022-0728(72)80500-X]

10. D.D. MacDonald, D. Owen, J. Electrochem. Soc. 123 (1976) 824.

11. D.D. MacDonald, B. Roberts, Electrochim. Acta 23 (1978) 557. [10.1016/00134686(78)85036-1]

12. D.D. MacDonald, B. Roberts, Electrochim. Acta 23 (1978) 781. [10.1016/00134686(78)80039-5]

13. G.T. Burstein, G.M. Ashley, Corrosion 39 (1983) 241.

14. J.O. Zerbino, J.R. Vilche, A.J. Arvia, J. Appl. Electrochem. 11 (1981) 703. [10.1007/BF00615174]

15. M. Jayalakshmi, V.S. Muralidharan, Corros. Rev. 12 (1994) 305.

16. S. Nathira Begum, V.S. Muralidharan, C. Ahmed Basha, Applied Surface Science 254 (2008) 2325. [10.1016/j.apsusc.2007.09.019]

17. R.S. Schrebler-Guzman, J.R. Vilche, A.J. Arvia, Electrochim. Acta 24 (1979) 395. [10.1016/0013-4686(79)87026-7]

18. R.S. Schrebler-Guzman, J.R. Vilche, A.J. Arvia, J. Appl. Electrochem. 11 (1981) 551. [10.1007/BF00616674]

19. D. MacDonald, B. Roberts, Electrochim. Acta 23 (1978) 781. [10.1016/00134686(78)80039-5]

20. D. Geana, A.A. Ei Miligy, W.J. Lorenz, J. Appl. Electrochem. 4 (1974) 337. [10.1007/BF00608976]

21. G. Kreysa, B. Hakansson, Electrochim. Acta 23 (1978) 61.

22. D.W. Shoesmith, P. Taylor, M.G. Bailey, B. Ikeda, Electrochim Acta 23 (1978) 903. [10.1016/0013-4686(78)87014-5

23. O.A. Albani, J.O. Zerbino, J.R. Vilche, A.J. Arvia, Electrochim Acta 31 (1986) 1403. [10.1016/0013-4686(86)87052-9

24. N. Sato, K. Kudo, R. Nishimura, J. Electrochem. Soc. 123 (1976) 1419. [10.1149/1.2132612

25. V.S. Muralidharan, Corrosion Reviews 21-4 (2003) 327. 